\title{
Plotin, Traité 19 (I, 2) Sur les Vertus. Introduction, traduction, commentaires et notes par Dominic J. O'Meara
}

Paris, Librairie Philosophique J. Vrin, 2018 (Bibliothèque des textes philosophiques. Les écrits de Plotin). 154 p., ISBN 978-2-7116-2857-5

\section{Suzanne Stern-Gillet}

\section{(2) OpenEdition}

\section{Journals}

Electronic version

URL: https://journals.openedition.org/philosant/3437

DOI: 10.4000/philosant.3437

ISSN: 2648-2789

\section{Publisher}

Éditions Vrin

\section{Printed version}

Date of publication: 31 October 2020

Number of pages: $290-292$

ISBN: 978-2-7116-2977-0

ISSN: 1634-4561

\section{Electronic reference}

Suzanne Stern-Gillet, "Plotin, Traité $19(1,2)$ Sur les Vertus. Introduction, traduction, commentaires et notes par Dominic J. O'Meara", Philosophie antique [Online], 20 | 2020, Online since 23 January 2019 connection on 10 December 2022. URL: http://journals.openedition.org/philosant/3437 ; DOI: https:// doi.org/10.4000/philosant.3437

\section{cc) (1) $\odot$}

Creative Commons - Attribution-NonCommercial-NoDerivatives 4.0 International - CC BY-NC-ND 4.0 https://creativecommons.org/licenses/by-nc-nd/4.0/ 
À ce titre, on voudrait pour finir souligner la qualité du travail conduit par la collection - devenue incontournable en histoire de la philosophie ancienne et moderne -, non seulement dans l'édition du livre papier, mais aussi dans l'effort de mise à disposition de leurs titres sous version électronique, un effort précieux, notamment pour les étudiantes et étudiants.

Gweltaz GuYomarc'H

Université de Lyon

Plotin, Traité 19 (I, 2) Sur les Vertus. Introduction, traduction, commentaires et notes par Dominic J. O'Meara, Paris, Librairie Philosophique J. Vrin, 2018 (Bibliothèque des textes philosophiques. Les écrits de Plotin). 154 p., ISBN 978-2-7116-2857-5.

O'Meara's translation and commentary of Ennead 19 (Sur les Vertus) is a short and elegant book: the style is sparse, the meaning limpid, and the thesis skilfully developed. The translation meticulously follows the movement of Plotinus' argumentation. Ample cross references are made to other tractates, and helpful mentions abound of secondary literature in languages other than French. The historical sections are short: Middle Platonist antecedents of Plotinus' theory of virtue are occasionally mentioned in footnotes and the influence of the tractate upon later Neoplatonists is succinctly recorded. Although O'Meara (henceforth O'M.) focuses on a subject currently much debated amongst Plotinian scholars, he eschews polemics.

I now turn to specifics. To account for Plotinus's articulation of the concept of virtue, O'M. turns to A.C. Lloyd's The Anatomy of Neoplatonism (1990). In the Neoplatonic frame of procession and causation, Lloyd argues in a book that is more often lauded than read, « forms are not transmitted identically from agent to effect, as they do for Aristotle, but are altered qualitatively when received by the effect $\gg(77)$. Since members of such a series (e.g. good, life, soul) do not possess their property synonymously, Lloyd goes on, they form a quasi-genus or P-series. Borrowing Lloyd's key concept to make it applicable to the Plotinian hierarchy of the virtues, O'M. writes: « si ... cet ordre de priorité s'applique à la vertu, nous pouvons en conclure que ce qui est commun aux deux types de vertus, ce qui fait que ce sont des 'vertus', n'est autre que le premier terme de l'ordre, c'est-à-dire les vertus 'supérieures' » (p. 77). True, but what makes some virtues superior to others is their closer relationship to the Forms in Intellect, which are the realities or archetypes by reference to which Plotinus conceives of the virtues in the human soul.

At the outset O'M. warns his reader not to expect to find in the tractate a theory of virtue or, even less, a summary of Plotinus' ethics, but only an exploration of the Platonic ideal of homoiosis theio (assimilation to god, p. 14). This is a curious view to take of a tractate in which Plotinus makes ethical mileage of one of his favourite Platonic passages. To become as just and good as humanly possible, Socrates had told Theaetetus, we must turn away from earth to heaven and assimilate ourselves to the divine. In tractate 19, through tidying up the paradoxes left in Plato's pithy formulation, Plotinus outlines his own, metaphysically based, analysis of some of the key concepts of Greek ethics, virtue, self-purification and assimilation to the divine. Why is this not ethics?

From his Platonopolis (2003) onwards, O'M. has sought to correct what he regards as a one-sided account of Plotinus' ethics according to which we are to turn away from practical affairs so as revert to the higher realities from which our soul is emanated. Against 
the weight of scholarly opinion so far, O'M. claims not only that Plotinus presents the practical life as a valuable second best for those who are unable to contemplate, but also that such a life can proceed from a deliberate choice on the part of those who are able to contemplate. « The soul who has 'reached divine life' », he writes, «... may wish to 'descend' to return to the exercise of 'political virtue' » (2003: 43). Since all the passages that he chooses to substantiate his interpretation deal with human interaction, we may infer that he takes ethics to be essentially concerned with the claims that others have on the virtuous agent.

From that point of view, it would seem, prima facie, that tractate 19 has little claim to be a treatise of ethics; even the civic virtue of justice is there presented as a disposition that the soul has to itself. Accordingly, to demonstrate that Plotinus finds value in the practical life, O'M. turns to tractate 28 , chapter 44 . Plotinus, so he claims, there holds that the human soul's « generous nature » prompts it to care for its conjoined body in a manner similar to the way in which the World-Soul takes providential care of the world of sense (106). « Generous » is an odd choice of word on O'M.'s part, both lexically (which Plotinian word does it render?) and semantically (is the virtue of generosity not a disposition deliberately to further the welfare of another?). As O'M. knows well, the World-Soul does not « choose » to do what it does (see, e.g., III 8 4) and, as Plotinus argues in tractate 19, it cannot be said to be virtuous. What we get in tractate 28.44, O'M. maintains, is a discussion of real-life choices, which any audience, past and present, would regard as sensible if not noble (gennaios): concern for the wellbeing of the body (one's own as well as that of others), ambition for political office and the decision to marry and have children. While this is true enough, Plotinus' examples should be taken in their context, which is a discussion of the « bewitchment (goeteia) » of the soul by appetites and passions. To the life of practical affairs, which is liable to be so « enchanted », he opposes the contemplative life, which is governed by reason and is thus immune to enchantment. To account for the force that leads sentient beings actively to aim at the satisfaction of urges that nature has implanted in them, Plotinus borrows from the Stoics the concept of oikeiosis. Taken as proceeding from oikeiosis, the above-mentioned practical choices, as Plotinus then appears reluctantly to concede, may « perhaps appear sensible » (44.23). O'M. takes this apparent concession to validate his interpretation: « Ici, le souci de la vie des autres et de sa propre vie s'opposerait au suicide ... la vie en cause est donc la vie en corps. On peut aussi supposer que l'âme, dans son souci du corps, se soucie aussi du bien-être (corporel) des autres. Dans le cadre d'un tel engagement de l'âme, il se peut que, dans certaines circonstances, le désir sexuel ait sa place, non pas comme puissance irrationnelle obsédante, mais dans la mesure où il est maitrisé par l'âme dans le libre exercice de son jugement » (106-107, italics mine). As suggested by his use of modal verbs and the conditional tense, O’M. has stretched Plotinus's words to the limit of their semantic possibilities.

Furthermore, the second half of the chapter shows that Plotinus, far from conceding anything, is actually warning the human soul who « contents herself with the nobility in practical actions, and chooses activity because [of being] deluded by its vestiges of nobility » (25-26) that it is, in reality, « bewitched » by failing to realise that the « nobility » of which it prides herself is but a semblance of nobility and that human souls who pursue « what is not good as if it was good » are « being ignorantly led where they do not want to go. » (30-33). The same contrast is drawn in tractate $52,15.13-17$ between men who are ruled by external circumstances, « as if enchanted, » and those who master them. Readers interested in the issue would benefit from Gurtler's balanced commentary on tractate 28 (Ennead IV.4.30-45 \& IV.5: Problems Concerning the Soul, 2015: 206-217). 
As the above-mentioned chapter shows, Plotinus is more inclined to downplay the worthiness of the practical life than to celebrate it. Although he is far from regarding it as inherently bad and does admit that circumstances in the world of sense may require the virtuous to forsake contemplation in favour of practical action, he stresses that such circumstances are rare and, more generally, that those who choose to bring children into the world and devote themselves to a life in politics are choosing the lesser path. Paradoxically, one of the few passages in which Plotinus encourages us to cultivate the civic virtues is in tractate 19: « it is unreasonable (alogon) to suppose that we are not made godlike in any way by the civic virtues, $\gg$ he writes (1.23-24) since these virtues « do genuinely set us in order and make us better by giving limit and measure into all our experience. » As O'M. rightly comments (78-82), the civic virtues are there presented as true virtues and claimed to fulfil a doubly valuable function. They enable human souls to put measure into their passions and appetites and they prepare the stronger souls amongst them to undertake the process of self-purification that goes hand in hand with the cultivation of the purificatory virtues.

If for that reason alone, tractate 19 would have a claim to being considered a treatise of ethics. But there are other reasons. First is Plotinus' doctrine of the perfectibility of the human embodied soul: what motivates it to seek to purify itself? Can it succeed in doing so and, if it can succeed, how is it to proceed? Second is the analysis of traditional categories and concepts of Greek ethics that Plotinus carries out in the tractate, namely the distinction between civic and purificatory virtues, the mutual implication of the virtues and the re-interpretation of Plato's definitions of the virtues in the Phaedo and the Republic. Why then challenge Plotinus' own assessment of the content of what became tractate 19 as the description of « the life of the good man » (7.12-13)? Admittedly, as Flamand has noted, « l'éthique de Plotin a quelque chose de déconcertant pour le lecteur d'aujourd'hui » (Sur les Vertus, in Brisson et Pradeau eds, 2003: 419). Plotinus' insistence on the supreme value of the life of contemplation may well shock modern readers whose ethical sensibilities have been shaped by a different, post-Augustinian, concept of virtue as essentially « other-regarding » but, if so, these readers would be well advised to take Plotinus on his own terms.

Despite the above objections, O'M.'s translation of, and commentary on, Ennead 19 has much to recommend itself and will stimulate debates for a long time to come. The book is well produced and free from typos and other blemishes.

Suzanne STERN-GiLlet University of Manchester (suzannesterngillet@gmail.com)

Noël Aujoulat et Adrien Lecerf, Hiéroclès d'Alexandrie, Commentaire sur les Vers d'or des Pythagoriciens; Traité sur la Providence, Textes introduits, traduits et annotés par Noël Aujoulat et Adrien Lecerf, Paris, Les Belles Lettres, 2018 (La Roue à Livres), 320 p., ISBN 978-2-2514-4798-8.

Noël Aujoulat est décédé le 9 janvier 2017. Il avait remis aux Belles Lettres un manuscrit qu'Adrien Lecerf a révisé et complété après sa mort. Ce livre résulte ainsi d'un travail à deux mains indépendantes. Après un avant-propos et une introduction (p. 1-80) sont proposés une traduction des Vers d'or eux-mêmes (p. 81-86), puis de leur Commentaire intégral par Hiéroclès (p. 91-220) ainsi que des extraits de son Traité sur la Providence recueillis par Photios (p. 221-247), des notes sur les deux textes, un index nonimum et rerum. 